\title{
ENVIRONMENTAL IMPACT ASSESSMENT OF PETROCHEMICAL INDUSTRY USING PROMETHEE APPROACH; CASE STUDY: ARAK, IRAN
}

\author{
Solmaz AMOOSHAHI ${ }^{1}$, Sharareh POUREBRAHIM ${ }^{2}$, Farhad NEJADKOORKI ${ }^{3}$ \\ 1, 3 Yazd University, Yazd, the Islamic Republic of Iran \\ ${ }^{2}$ Department of Environment, Faculty of Natural Resources, University of Tehran, Iran
}

Received 02 November 2016; accepted 11 September 2017

\begin{abstract}
Due to the significant importance of petrochemical industry for Iran's national economy and the environmental impacts such as wastewater, pollutant emissions, and hazardous wastes, the present study aimed to assess the construction and operation in two phases. Some relevant criteria were distinguished and weighted using Shannon's entropy, as the objective weighting measures used to measure uncertainty, occurrence probability, severity, and vulnerability, and expert knowledge. The PROMETHEE technique was used due to the presence of large volumes of quantitative and qualitative data and its capability to evaluate the impacts. The steps included forming the evaluation matrix, determining the preference functions and function calculations. The relative desirability of each alternative was measured by calculating the net outranking flows. Finally, the activities were ranked. Based on the results, the main environmental negative impacts are the loss of vegetation cover and land use change, soil erosion and water and air pollution due to activities such as land cleanly shaven, establishment and operation of fuel tanks and drainage changes.
\end{abstract}

Keywords: EIA, environmental protection, outranking method, environmental monitoring.

\section{Introduction}

Iran, as the world's fourth largest oil producer and the owner of the second largest gas reserves, gains $80 \%$ of its export revenues by selling these resources. On one hand, new circumstances in the world such as emerging interest in the use of renewable energy, falling oil prices, increased technical capacity, policies to prevent environmental pollution, global warming, as well as Iran's scientific and political situation in the world, have affected the profitable industry of petrochemical products. Thus, petroleum and petrochemical industries appear to be the most important industries in Iran, while the petrochemical industry is ranked as the first in terms of economy (Saket 2016).

Currently, Iran has 55 petrochemical complexes that the most important ones are located in big cities (National Petrochemical Company 2016). With regard to the issues cited, the petrochemical industries in this developing country have progressed substantially.

The impacts of petrochemical industry on the region and the world, including producing waste, wastewater and gaseous effluent can be deleterious for the surface water, groundwater, soil, biodiversity, human and the buildings. Due to contamination of the underground and surface water used by local people, the waste storage stations can cause significant health hazards. Air emissions containing sulfur oxides, nitrogen oxides, dust, benzene and carbon monoxides can significant affect the humans (Olivier et al. 2015). In addition, some of other petrochemical industries purge gas, containing ammonia, methane, nitrogen, argon, $\mathrm{CO}_{2}$, and hydrogen. These materials contain gases with relatively high heating levels, especially in case of methane and $\mathrm{CO}_{2}$. They are greenhouse gases with irreversible impacts on regional and global areas (Esma'ilzadeh, Mohammad Shahi 2009). Methane is known as a very important greenhouse gas that is hundred times more powerful than $\mathrm{CO}_{2}$ (Howarth 2015). This gas is also responsible for ozone depletion (Broucek 2014). $\mathrm{CO}_{2}$ emitting, as a very effective greenhouse gas, has very important impacts on cities' temperature and the health of humans, animals, and plants (Olivier et al. 2015). The noise effect of petrochemical industries can cause different harmful effects on staffs, people, and animals around the petrochemical complexes (Peszko et al. 2006).

Environmental impact assessment (EIA) is a process that includes identification, prediction, evaluation and mitigation of these impacts proposed by the decision-makers and commissions (Suopajärvi 2013; Deng et al. 2014;

*Corresponding author. E-mail: sh_pourebrahim@ut.ac.ir 
Simion et al. 2013). There are many different methods to assess the impacts of development on the environment. To select a suitable method, we need to consider some elements such as the method properties, environmental properties and project nature (Duarte et al. 2007; Rodrigues et al. 2003; Wang et al. 2006; Abromas et al. 2015). The most important factor to develop EIA is encouraging the decision-makers to pay attention to the environment to do some environmental friendly activities (Hosseini et al. 2012; Achilas et al. 2011; Huang et al. 2010).

In previous studies, various methods have been implemented for environmental impact assessment projects such as rapid impact assessment, life cycle assessment, uncertainty methods, Degradation Model, Analytical Hierarchy Process (AHP) and ELECTRE.

In this research, the concept of Shannon's entropy with an important role in information theory was applied to measure the degree of randomness (Lotfi, Fallahnejad 2010).

For rapid impact assessment matrix, Pastakia and Jensen (1998) found that the mentioned matrix visualizes the results and is capable of easily testing different options; thus, this method is a powerful tool for EIA. They declared that the method provides a transparent, clear and permanent record of judgment as well. Gilbuena et al. (2013) demonstrated that the RIAM model provides clear results. In 2004, Pennington $e t$ al. used life cycle assessment model as a very useful method for uncertain data. In 2006, Wang et al. applied uncertainty method and mentioned that the detailed implementation process of the method makes it a suitable model for EIA. Kaya and Kahraman (2011) used integrated fuzzy AHP-ELECTRE. They found that the sensitivity trait and enough details make it an appropriate method for EIA. Khodabakhshi and Jafari (2010) used ELECTRE for EIA process. Some researchers applied REGIME method, Overlay method and Matrix method, respectively (Papadopoulou, Antoniou 2014; Sharafi et al. 2008). In recent years, PROMETHEE (Preference Ranking Organization Method for Enrichment Evaluations) has been regarded as one of the most efficient multi-criteria decision-making methods (Kaya, Kahraman 2011; Cloquell-Ballester et al. 2007; Kiker et al. 2005; Latawiec et al. 2017; Amaral, Coasta 2014). The PROMETHEE method was presented by Brans and Mareschal in 1994 to handle qualitative and discrete alternatives (Corrente et al. 2014). This method is a preferred organizational method, which is applied to rank the alternatives based on pair-wise comparisons and is capable of ranking the proposed alternatives in decision-making problems (Behzadian et al. 2010). In 1999, Al-Rashdan et al. used the PROMETHEE to carry out the environmental impact assessment and to rank water resources in Jordan as an environmental subject. In the mentioned research, they expressed that the proposed methodology is a suitable one for the process of environmental decision-making and selecting or ranking of environmental projects. Kabir and Sumi (2014) successfully employed this method in case of other environmental issues. In the present study, the PROMETEE was used for environmental impact assessment of petrochemical industry.

\section{Methodology}

\subsection{Characteristics of the study area}

Arak Petrochemical Company was selected as the study area. This company is located near the Arak's seventh refinery, on the $22 \mathrm{kmof}$ Arak main road with an altitude of 1888 meters above the sea level. It is located near Arak in Markazi province. Arak is one of the most important metropolises of Iran and also one of the most polluted cities (Norouzi, Shamsipour 2015; Ansari 2015). As pointed out by Karam et al. (2014), Arak pollution is more than Tehran on some factors such as Carbon Monoxide (CO). This city is located in a mountainous region and encompasses some environmentally sensitive areas such as Rasvand wildlife refuge and Chalkhatoun hunting prohibited area. The mentioned areas include endangered and vulnerable fauna and flora species (Abdi 2008; Raesi, Bijani 2016; Iran environmental protection agency 2011). This is one of the major infrastructural projects that have been created at overall development policies of petrochemical industries aimed to supply the domestic needs and export the surplus products. Figure 1 shows the location of study area.

\subsection{Identification of criteria and activities}

In the present study, two constructional and operational phases were considered in Arak petrochemical company. In the first step, all activities in these phases were determined. The activities were selected in a specific workshop based on physical, biological, geographical and environmental conditions of the production and manufacturing process of Arak petrochemical complex. The constructional phase and operational phases included 17 and 8 activities, respectively. The activities in construction phase included Land cleanly shaven (A1); Site preparation and excavation (A2); Road construction and segmentation (A3); Drainage changes (A4); Digging and building (A5), Waste production (A6); Human and industrial wastewater treatment plants (A7) Collection and disposal of waste(A8); Establishment and operation of fuel tanks(A9); Compressor, welder and generator activities (A10); Assembly of equipment and tanks (A11); Camps, buildings and workshops construction (A12); Well platform, water and solid waste pit construction (A13); The construction of oil, gas and water pipelines (A14); Well Drilling (A15); Manpower employment (A16); Land ownership (A17).

The activities in the operational phase were as follows: The operation of the units (A1); Management and collection of waste (A2); food, products and personnel transportation (A3); Waste collection and management (A4); Extraction of groundwater (A5); Hiring employees (A6); Welfare Services (A7); Commissioning of chimneys and burners (A8).

Afterwards, to achieve the desired criteria and investigate the environmental impact of each activity, a smart 

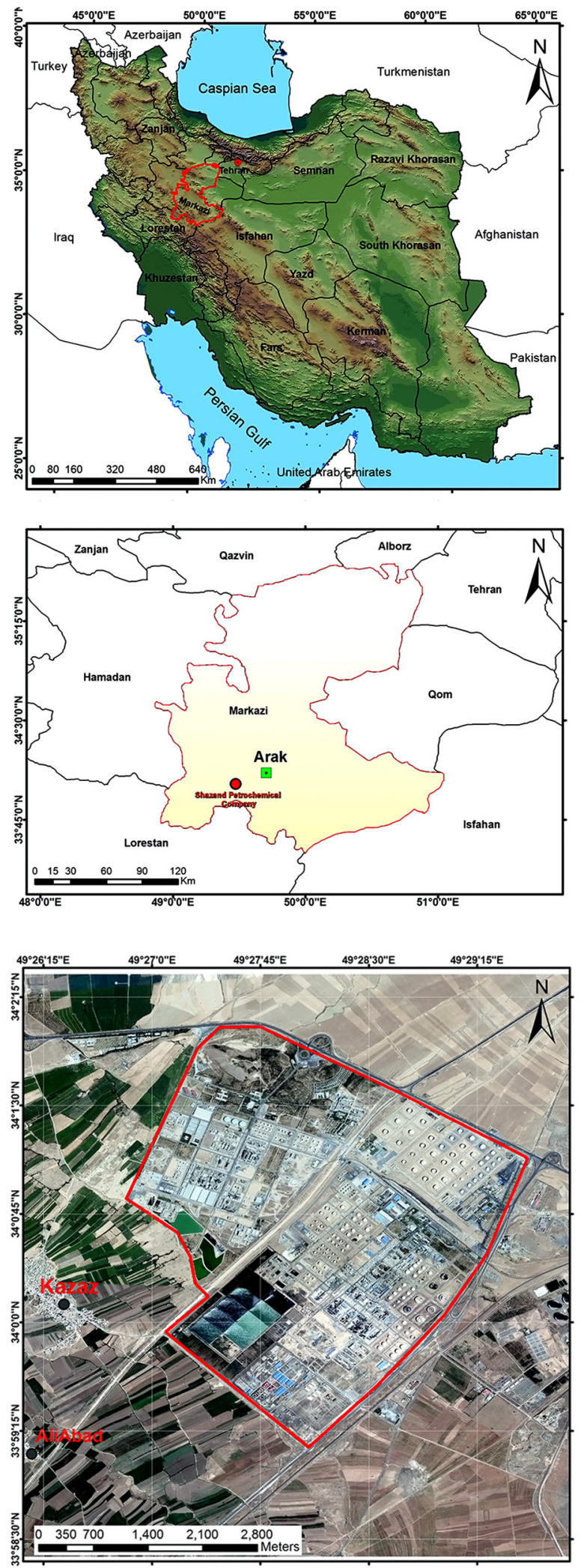

Legend

Capital $\star$ C Center of Province $\bullet$ Province Boundary $\square$ Geoghraphic Cordinate System: GCS_WGS_1984

Figure 1. Arak petrochemical company location filter was developed based on the eight most widely used criteria, including Magnitude $\left(\mathrm{C}_{1}\right)$, Extent $\left(\mathrm{C}_{2}\right)$, Continuity $\left(\mathrm{C}_{3}\right)$, Accumulative effect $\left(\mathrm{C}_{4}\right)$, Reduction strategy $\left(\mathrm{C}_{5}\right)$, Positive/ Negative $\left(\mathrm{C}_{6}\right)$, Direct/ Indirect $\left(\mathrm{C}_{7}\right)$ and Reversibility $\left(\mathrm{C}_{8}\right)$.

Experts' knowledge in different specific workshops was obtained to weight the activities based on the smart filter. This matrix was developed separately in the constructional and operational phases. For this purpose, at first, a specific workshop was held with attending of 20 petrochemical industries experts to identify the activities. Then, two workshops were organized by attending of 30 experts from the department of environment, department of natural resources and universities professors to evaluate the activities based on different questionnaires.

To import all criteria into the model, in the same scale and quantitatively, each criterion should be placed in the relevant score domain. A questionnaire was designed based on selected activities and criteria on a scale of 1-5 to show the lowest to highest impacts, and the experts' knowledge indifferent fields of Arak petrochemical engineers, environmental Scientists, Arak's Department of Natural Resources and Department of Environment experts were used for scoring various alternatives. The criteria values coordination was controlled by calculating the values of standard deviation obtained from the questionnaires. In fact, this process was done to ensure the coordination of experts' judgments.

\subsection{Alternatives ranking by using PROMETHEE}

To obtain the best preference order, at first, a payoff matrix was needed with the information about the alternatives, criteria, weights, and evaluation of each alternative for each criterion. The PROMETHEE method presents an outranking method for a fixed set of alternatives. The preference function defines the rank of one option with respect to another and translates the deviation between two parallel alternatives into a unique parameter, which is associated with the degree of preference. The degree of preference presents a growing deviation function, whereby, in the case of small deviation, it refers to a weak preference and in the case of large deviation, it represents a strong preference associated with a reference alternative. The PROMETHEE method has at its disposal six possible shapes of preferential functions (Usual, U-shape, V-shape, Level, V-shape with indifferences and Gaussian) as presented in Figure 2. (Greco et al. 2005). Every shape depends on two thresholds $(Q$ and $P$ ). The indifference threshold $(Q)$ represents the maximum deviation that the decision maker considers unimportant, while the preference threshold $(P)$ represents the minimum deviation, which seems to be decisive for the decision maker, where $P$ is not allowed to be smaller than $Q$. The Gaussian threshold $(S)$ represents a mean value between the thresholds $P$ and Q (Brans, Mareschal 1994; Benabied et al. 2012; Greco et al. 2005).

Based on Figure 2, criteria types and function types are defined as Table 1. 
The PROMETHEE method is based on determining the positive $(\Phi+)$ and the negative flow $(\Phi-)$ for each alternative towards outranking relations and in correlation with the acquired weight coefficients for each criterion-attribute (Eq. (1) and Eq. (2)). In other words, the PROMETHEE is carried out based on the pair-wise comparison that shows how much each alternative is dominant compared to other alternatives. For alternative $a$,

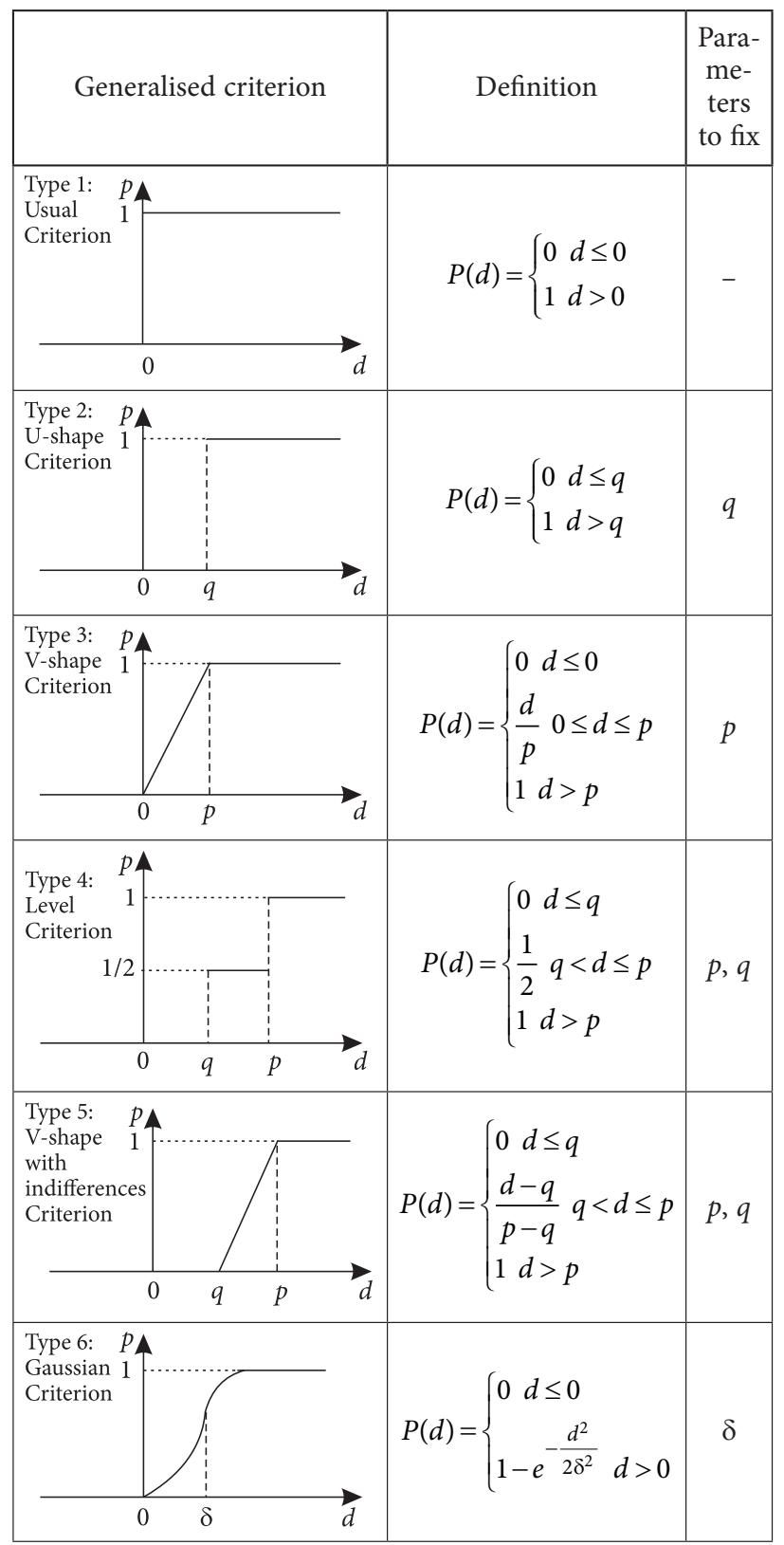

Figure 2. PROMETHEE appropriate functions (Greco et al. 2005) belonging to set $A, \pi(a, b)$ indicates overall preference of over and vice versa:

$$
\begin{aligned}
& \varphi^{+}(a)=\frac{1}{n-1} \sum_{x \in A} \pi(a, x), \\
& \varphi-(a)=\frac{1}{n-1} \sum_{x \in A} \pi(x, a) .
\end{aligned}
$$

The positive preference flow expresses how much an alternative dominates over the others. So, $\varphi^{+}(a)$ states how much the alternative $a$ is superior to other alternatives belonging to the set; therefore, the greater the value, the more significant is the alternative. The negative preference flow expresses the preference of all the other alternatives compared to the analyzed one. Thus, $\varphi^{-}(a)$ demonstrates that how much other outranked characters of set $A$ are superior to $a$ alternative. Therefore, an alternative is more important if the value of the output flow will be smaller. The complete ranking of PROMETHEE is based on the calculation of a net outranking flow value $(\Phi)$ that represents the balance between the positive and the negative outranking flows. The higher the net flow is the better the alternative. Accordingly, if the alternative has a greater positive $(\Phi+)$ and a lower negative flow $(\Phi-)$, then, the net outranking flow $(\Phi)$ for this alternative is higher (Eq. (3)). For the investigations presented in this study, this would mean that such an alternative has a larger significance compared to the other (Jafari 2013; Greco et al. 2005):

$$
\varphi(a)=\varphi^{+}(a)-\varphi^{-}(a) .
$$

In addition, Entropy method was used to calculate the weights employed in PROMETHEE (Asgharpour 2011). Avoiding the subjective factors, entropy was adapted to calculate the weights. For Entropy, at first, the judgment matrix was normalized using Eq. (4):

$$
n_{i j}=\frac{r_{i j}}{\sum_{i=1}^{m} r_{i j}},
$$

where $n_{i j}$ - normalized number; $r_{i j}$ - each member of the decision matrix; $\sum_{i=1}^{m} r_{i j}$ - sum of the $j^{\text {th }}$ column (for $X^{\text {th }}$
criterion).

If the system is in a variety of different states and the probability of each state to appear is $p_{i}(i=1,2 \ldots m)$, the entropy of the system can be defined as Eq. (5).

$$
E=-k \sum_{i=1}^{n}\left[p_{i} \cdot \ln p_{i}\right]
$$

where $p_{i}$ - discrete probability distribution.

Table 1. Criteria type and function

\begin{tabular}{|l|l|l|l|l|l|l|l|l|}
\hline & Magnitude & \multicolumn{1}{|c|}{ extent } & Continuity & $\begin{array}{c}\text { Accumulative } \\
\text { effect }\end{array}$ & $\begin{array}{c}\text { Reduction } \\
\text { strategy }\end{array}$ & $\begin{array}{c}\text { Positive/ } \\
\text { Negative }\end{array}$ & $\begin{array}{c}\text { Direct/ } \\
\text { Indirect }\end{array}$ & Reversibility \\
\hline Indices type & Decreasing & Decreasing & Decreasing & Decreasing & Decreasing & Decreasing & Decreasing & Decreasing \\
\hline $\begin{array}{l}\text { Function } \\
\text { type }\end{array}$ & Type 4 & Type 4 & Type 4 & Type 4 & Type 4 & Type 5 & Type 4 & Type 4 \\
\hline
\end{tabular}


Table 2. Geo mean matrix of constructional phase

\begin{tabular}{|c|c|c|c|c|c|c|c|c|}
\hline GEO MEAN & Magnitude & Extent & Continuity & $\begin{array}{l}\text { Accumu- } \\
\text { lative effect }\end{array}$ & $\begin{array}{l}\text { Reduction } \\
\text { strategy }\end{array}$ & $\begin{array}{l}\text { Positive/ } \\
\text { Negative }\end{array}$ & $\begin{array}{l}\text { Direct/ } \\
\text { Indirect }\end{array}$ & Reversibility \\
\hline Land cleanly shaven & 2.710 & 1.681 & 2.710 & 1.732 & 2.213 & 2.279 & 3 & 2.449 \\
\hline $\begin{array}{l}\text { Site preparation and } \\
\text { excavation }\end{array}$ & 2.449 & 2.213 & 1.681 & 1.414 & 2 & 2.279 & 3 & 2.279 \\
\hline $\begin{array}{l}\text { Road construction } \\
\text { and segmentation }\end{array}$ & 2.059 & 2.213 & 2.449 & 2.213 & 1.861 & 2.279 & 1.732 & 2.710 \\
\hline Drainage changes & 2.710 & 1.189 & 2.449 & 2.279 & 2.449 & 2.449 & 1.732 & 2.449 \\
\hline Digging and building & 2.213 & 1.861 & 1.681 & 1.414 & 1.414 & 2.279 & 2.279 & 1.861 \\
\hline Waste production & 2.213 & 1.861 & 1.861 & 1.189 & 1.189 & 2.279 & 2.279 & 1.861 \\
\hline $\begin{array}{l}\text { Human and indust- } \\
\text { rial wastewater treat- } \\
\text { ment plants }\end{array}$ & 1.414 & 1.414 & 1.732 & 1.189 & 1.681 & 1 & 2.279 & 2.279 \\
\hline $\begin{array}{l}\text { Collection and dis- } \\
\text { posal of waste }\end{array}$ & 1.681 & 2 & 1.414 & 1.414 & 1.316 & 1.316 & 3 & 1.316 \\
\hline $\begin{array}{l}\text { Establishment and } \\
\text { operation of fuel } \\
\text { tanks }\end{array}$ & 2.213 & 2.213 & 2.059 & 2 & 2.059 & 2.279 & 3 & 2.059 \\
\hline $\begin{array}{l}\text { Compressor, welder } \\
\text { and generator acti- } \\
\text { vities }\end{array}$ & 1.414 & 1.681 & 1.414 & 1.189 & 1.189 & 2.710 & 3 & 1.189 \\
\hline $\begin{array}{l}\text { Assembly of equip- } \\
\text { ment and tanks }\end{array}$ & 1.861 & 1.681 & 2.449 & 1.414 & 1.681 & 2.279 & 1.732 & 2.449 \\
\hline $\begin{array}{l}\text { Camps, buildings and } \\
\text { workshops const- } \\
\text { ruction }\end{array}$ & 1.861 & 1.681 & 1.414 & 1.681 & 1.189 & 2.059 & 2.279 & 1.732 \\
\hline $\begin{array}{l}\text { Well plat form, water } \\
\text { and solid waste pit } \\
\text { construction }\end{array}$ & 2.449 & 2.449 & 2.059 & 2.059 & 2 & 2.059 & 1.732 & 2.059 \\
\hline $\begin{array}{l}\text { The construction of } \\
\text { oil pipelines and gas } \\
\text { and water }\end{array}$ & 1.681 & 2.710 & 2.213 & 1.414 & 2 & 2.279 & 1.732 & 2.449 \\
\hline Well Drilling & 2.279 & 1.414 & 1.565 & 2.059 & 2 & 2.059 & 3 & 2.449 \\
\hline $\begin{array}{l}\text { Manpower employ- } \\
\text { ment }\end{array}$ & 1.681 & 2.449 & 1.414 & 1.189 & 1.189 & 1 & 1.732 & 1.189 \\
\hline Land ownership & 3 & 2.213 & 3 & 2.449 & 3 & 2.279 & 3 & 3 \\
\hline SUM & 35.896 & 32.930 & 33.570 & 28.303 & 30.434 & 35.171 & 40.510 & 35.785 \\
\hline STDEV & 0.464 & 0.419 & 0.500 & 0.428 & 0.510 & 0.487 & 0.572 & 0.523 \\
\hline
\end{tabular}

Table 3. Geo mean matrix of operational phase

\begin{tabular}{|l|c|c|c|c|c|c|c|c|}
\hline \multicolumn{1}{|c|}{ GEO MEAN } & $\begin{array}{c}\text { Magni- } \\
\text { tude }\end{array}$ & Extent & $\begin{array}{c}\text { Conti- } \\
\text { nuity }\end{array}$ & $\begin{array}{c}\text { Accumu- } \\
\text { lative effect }\end{array}$ & $\begin{array}{c}\text { Reduction } \\
\text { strategy }\end{array}$ & $\begin{array}{c}\text { Positive/ } \\
\text { Negative }\end{array}$ & $\begin{array}{c}\text { Direct/ } \\
\text { Indirect }\end{array}$ & $\begin{array}{c}\text { Rever- } \\
\text { sibility }\end{array}$ \\
\hline The operation of the units & 3 & 1.732 & 3 & 3 & 2.710 & 2.279 & 3 & 3 \\
\hline Management and collection of waste & 1.565 & 1.861 & 2.710 & 1.316 & 1.861 & 1 & 2.279 & 1.861 \\
\hline $\begin{array}{l}\text { food, products and personnel } \\
\text { transportation }\end{array}$ & 1.861 & 2.059 & 2.710 & 2.213 & 2.449 & 2.059 & 2.279 & 2.213 \\
\hline Waste collection and management & 1.565 & 1.861 & 2.710 & 1.316 & 1.861 & 1 & 3 & 1.681 \\
\hline Extraction of groundwater & 3 & 2.059 & 2.710 & 2.710 & 2.213 & 2.279 & 3 & 2.213 \\
\hline Hiring employees & 1.414 & 2.710 & 2.449 & 1.732 & 1.861 & 1 & 2.279 & 1.861 \\
\hline Welfare Services & 1.681 & 2.213 & 2.213 & 1.681 & 1.414 & 1.189 & 2.710 & 2.213 \\
\hline $\begin{array}{l}\text { Commissioning of chimneys and } \\
\text { burners }\end{array}$ & 2.449 & 2.449 & 2.449 & 2.449 & 2.213 & 2.279 & 3 & 2.213 \\
\hline SUM & 16.536 & 16.947 & 20.955 & 16.419 & 16.584 & 13.087 & 21.549 & 17.257 \\
\hline STDEV & 0.655 & 0.329 & 0.239 & 0.636 & 0.406 & 0.636 & 0.356 & 0.400 \\
\hline
\end{tabular}


Generally, $k$ is always a positive constant value, which must provide the condition $0 \leq E \leq 1 . \mathrm{K}$ and can be calculated as Eq. (6):

$$
k=\frac{1}{\ln m}
$$

where $m$ - number of alternatives.

After calculating, the information entropy of indicators is $E_{1}, E_{2} \ldots E_{n}$, Then, $d_{j}$ should be calculated by Eq. (7):

$$
d_{j}=1-E_{j} ; \forall_{j},
$$

where $d_{j}$ - deviation.

Calculate the Shannon's entropy weight of evaluation index as Eq. (8):

$$
W_{j}=\frac{d_{j}}{\sum_{j=1}^{n} d_{j}} ; \forall_{j} .
$$

In this research, to detect which alternative is located in which specific class, the domain, and range of each class were determined using the profile or classes boundaries (Khodabakhshi, Jafari 2010; San Cristobal 2012). The range of project impacts is divided into five classes, including very high negative impact, main negative impact, medium negative impact, low negative impact and negligible negative impact. Thus, based on Eq. (9), these classes were determined. In this formula, criteria score domain (A) is Maximum criteria Score - Minimum criteria Score:

$$
X=\frac{A}{n},
$$

where $A$ - criteria score domain; $n$ - classes number, $X$ classes interval.

\section{Results and discussion}

As mentioned in methodology, since there were different criteria with different weights by experts, the geo-mean value was used. The results of the matrix in the two phases are presented in Tables 2, 3 .

As indicated, due to the mountainous trait of Arak region and physical characteristics of area's soil and rock, most of the important impacts are related to the constructional phase. Among these factors, negative impacts are more than the positive ones.

Criteria values coordination was controlled by calculating the standard deviation of values obtained from questionnaires. Table 4 shows the results in two phases.
As previously explained, criteria weights have a significant role in determining the positive and negative impacts of projects. Obtained standard deviation data in two constructional and operational phases are less than 1. So, these data are reliable for next stages. Criteria weighting has been done by using Shannon's entropy technique. The result is mentioned in Table 5.

Table 5. The final criteria weights in two different phases

\begin{tabular}{|l|c|c|c|c|c|c|c|c|}
\hline & $\mathrm{C}_{1}$ & $\mathrm{C}_{2}$ & $\mathrm{C}_{3}$ & $\mathrm{C}_{4}$ & $\mathrm{C}_{5}$ & $\mathrm{C}_{6}$ & $\mathrm{C}_{7}$ & $\mathrm{C}_{8}$ \\
\hline $\begin{array}{l}\text { Const- } \\
\text { ructional } \\
\text { phase }\end{array}$ & 0.09 & 0.09 & 0.12 & 0.13 & 0.16 & 0.13 & 0.11 & 0.13 \\
\hline $\begin{array}{l}\text { Operatio- } \\
\text { nal phase }\end{array}$ & 0.2 & 0.05 & 0.01 & 0.2 & 0.08 & 0.32 & 0.03 & 0.07 \\
\hline
\end{tabular}

According to the obtained data, the maximum weight in constructional phase belongs to reduction strategy criterion and in operational phase is a positive or negative criterion. The result of weight ranges to determine five classes shown in Constructional phase, $A=0.065$ and $X=$ 0.013 in the operational phase, $A=0.311$ and $X=0.062$. Based on this category, the result is presented in Table 6.

Table 6. Categories of environmental impact in two different phases

\begin{tabular}{|l|c|c|c|c|c|}
\hline & $\begin{array}{c}\text { Negli- } \\
\text { gible } \\
\text { negative } \\
\text { impact }\end{array}$ & $\begin{array}{c}\text { Low } \\
\text { negative } \\
\text { impact }\end{array}$ & $\begin{array}{c}\text { Medium } \\
\text { negative } \\
\text { impact }\end{array}$ & $\begin{array}{c}\text { Main } \\
\text { negative } \\
\text { impact }\end{array}$ & $\begin{array}{c}\text { Very } \\
\text { high } \\
\text { negative } \\
\text { impact }\end{array}$ \\
\hline $\begin{array}{l}\text { Const- } \\
\text { ructional } \\
\text { phase }\end{array}$ & $\begin{array}{c}0.096- \\
0.109\end{array}$ & $\begin{array}{c}0.109- \\
0.122\end{array}$ & $\begin{array}{c}0.122- \\
0.135\end{array}$ & $\begin{array}{c}0.135- \\
0.148\end{array}$ & $\begin{array}{c}0.148- \\
0.161\end{array}$ \\
\hline $\begin{array}{l}\text { Operatio- } \\
\text { nal phase }\end{array}$ & $0.017-$ & $0.080-$ & $0.142-$ & $0.204-$ & $0.267-$ \\
0.142 & 0.204 & 0.267 & 0.329 \\
\hline
\end{tabular}

The positive and negative outranking flow expresses how an alternative is outranking all the others. It is its power, its outranking character. The higher $\varphi^{+}(a)$ means the better the alternative. The lower $\varphi^{-}(a)$ is the worth the alternative. The results of positive, negative and net flows in two different phases are presented in Table 7.

The results of construction and operational outranking in DECISION LAB software is presented in Figures 3 and 4.

Based on the above results, final outranking in construction phase is as follows:

$\mathrm{A} 17>\mathrm{A} 1>\mathrm{A} 9>\mathrm{A} 4>\mathrm{A} 3>\mathrm{A} 2>\mathrm{A} 14>\mathrm{A} 15>\mathrm{A} 13>\mathrm{A} 11>\mathrm{A} 5>$ $\mathrm{A} 8>\mathrm{A} 7>\mathrm{A} 6>\mathrm{A} 12>\mathrm{A} 10>\mathrm{A} 16$.

Table 4. Control of values coordination in two phases

\begin{tabular}{|l|c|c|c|c|c|c|c|c|}
\hline & Magnitude & Extent & Continuity & $\begin{array}{c}\text { Accumulative } \\
\text { effect }\end{array}$ & $\begin{array}{c}\text { Reduction } \\
\text { strategy }\end{array}$ & $\begin{array}{c}\text { Positive/ } \\
\text { Negative }\end{array}$ & $\begin{array}{c}\text { Direct/ } \\
\text { Indirect }\end{array}$ & Reversibility \\
\hline $\begin{array}{l}\text { Constructional } \\
\text { phase }\end{array}$ & 0.46 & 0.41 & 0.50 & 0.42 & 0.51 & 0.48 & 0.57 & 0.52 \\
\hline $\begin{array}{l}\text { Operational } \\
\text { phase }\end{array}$ & 0.65 & 0.32 & 0.23 & 0.63 & 0.40 & 0.63 & 0.35 & 0.40 \\
\hline
\end{tabular}




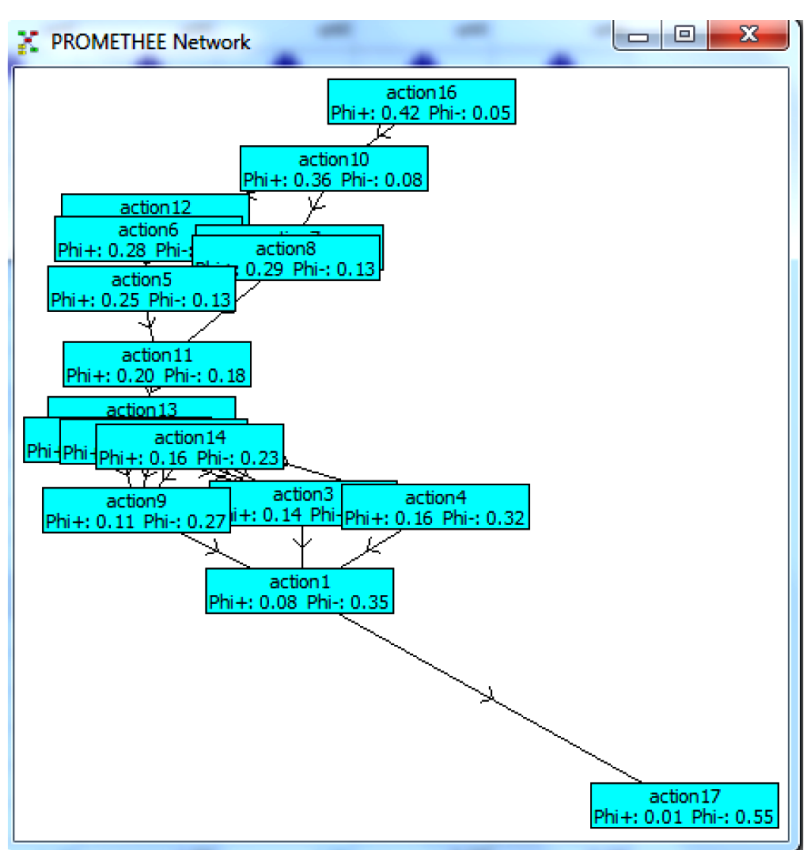

Figure 3. Alternatives outranking in constructional phase

Table 7. Positive, negative and net flows

\begin{tabular}{|c|c|c|c|}
\hline \multicolumn{4}{|c|}{ Constructional phase } \\
\hline & $\varphi^{+}$ & $\varphi^{-}$ & $\varphi$ \\
\hline $\mathrm{A} 1$ & 0.351425 & 0.080469 & 0.270956 \\
\hline $\mathrm{A} 2$ & 0.248407 & 0.143647 & 0.10476 \\
\hline A3 & 0.291519 & 0.141962 & 0.149556 \\
\hline $\mathrm{A} 4$ & 0.3151 & 0.161905 & 0.153194 \\
\hline A5 & 0.12633 & 0.251159 & -0.12483 \\
\hline A6 & 0.096484 & 0.283299 & -0.18682 \\
\hline A7 & 0.125375 & 0.301104 & -0.17573 \\
\hline A8 & 0.131803 & 0.295073 & -0.16327 \\
\hline A9 & 0.269333 & 0.106431 & 0.162903 \\
\hline A10 & 0.083294 & 0.359871 & -0.27658 \\
\hline A11 & 0.178491 & 0.200955 & -0.02246 \\
\hline A12 & 0.077796 & 0.300226 & -0.22243 \\
\hline A13 & 0.20862 & 0.164143 & 0.044477 \\
\hline A14 & 0.234053 & 0.15489 & 0.079163 \\
\hline A15 & 0.22873 & 0.175366 & 0.053363 \\
\hline A16 & 0.051307 & 0.421614 & -0.37031 \\
\hline A17 & 0.533103 & 0.009054 & 0.524049 \\
\hline \multicolumn{4}{|c|}{ Operational phase } \\
\hline A1 & 0.374357 & 0.025 & 0.349357 \\
\hline A2 & 0.022464 & 0.283106 & -0.26064 \\
\hline A3 & 0.135979 & 0.087543 & 0.048436 \\
\hline A4 & 0.023643 & 0.279891 & -0.25625 \\
\hline A5 & 0.2925 & 0.043286 & 0.249214 \\
\hline A6 & 0.081 & 0.225591 & -0.14459 \\
\hline A7 & 0.070071 & 0.216061 & -0.14599 \\
\hline A8 & 0.216107 & 0.055643 & 0.160464 \\
\hline
\end{tabular}

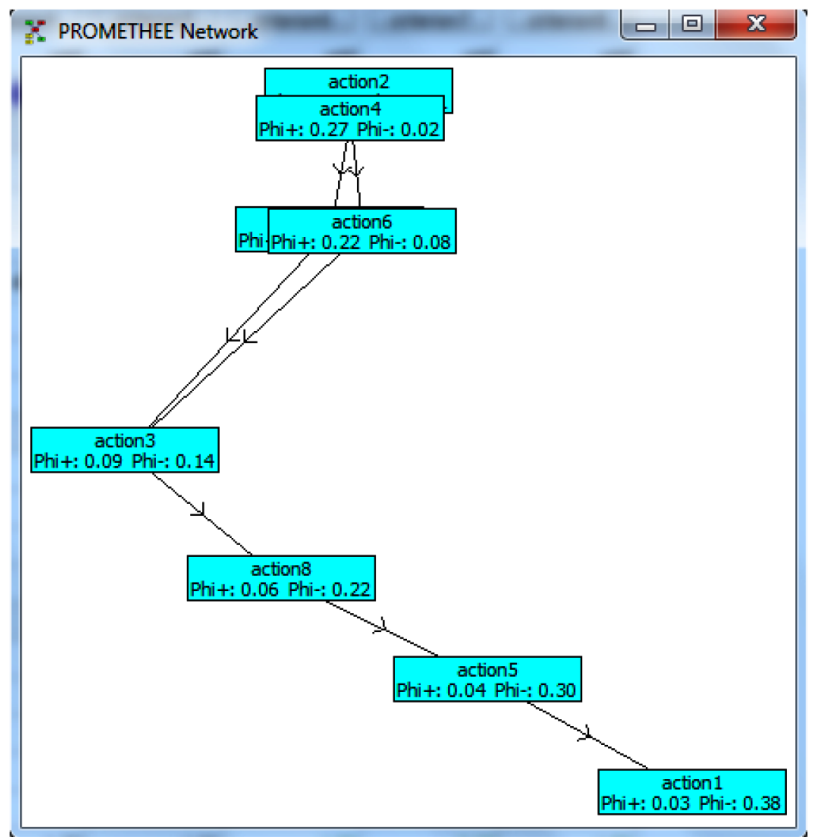

Figure 4. Alternatives outranking in operational phase

Therefore, the most significant impacts areas are land ownership, land cleanly shaven, establishment and operation of fuel tanks and drainage changes. Also, final outranking in operational phase is as follows:

$\mathrm{A} 1>\mathrm{A} 5>\mathrm{A} 8>\mathrm{A} 3>\mathrm{A} 6>\mathrm{A} 7>\mathrm{A} 4>\mathrm{A} 2$.

Therefore, the most significant impacts include the operation of units and extraction of groundwater.

After gaining the PROMETHEE results, considered impacts were classified based on the degree of importance into $\mathrm{A}$ to $\mathrm{D}$. The activities listed in $-\mathrm{D}$ and $-\mathrm{C}$ classes have negative impacts of the mentioned project. Accordingly, for constructional phase, land ownership (A17), land cleanly shaved (A1), establishment and operation of fuel tanks (A9) and drainage changes (A4) were categorized into-D class. Land ownership is one of the most important environmental issues, including some environmental and social negative impacts. Seize estate can be cited as the most significant social impact of the mentioned factors, and most of the time, it leads to heavy consequences. In many cases, estates seize leads to village destruction. Rural population migrates to other regions, especially to urban areas, and finally change their jobs and livelihoods. Other impacts of land ownership that can be classified as environmental impacts are the destruction of vegetation and land use changes. The parameters stated about A17 are common with land cleanly shaven. Establishment and operation of fuel tanks (A9) will start main changes in the ecosystem. Soil drainage change in farmlands makes some problems such as water logging, salinization, the soil erosion and flooding in the study region.

Road construction and segmentation (A3), site preparation and excavation (A2), the construction of oil, gas and water pipelines (A14) and Well Drilling (A15) are categorized in the $\mathrm{C}$ class. Some of the disadvantages of 
Table 8. Pastakia matrix in constructional phase

\begin{tabular}{|c|c|c|c|c|c|c|c|c|c|c|}
\hline \multicolumn{2}{|r|}{ Components } & \multicolumn{5}{|c|}{ RIAM Criteria Scores } & \multirow{2}{*}{$\begin{array}{c}\text { Score } \\
\text { ES }\end{array}$} & \multirow{2}{*}{$\begin{array}{c}\text { Value } \\
\text { RV }\end{array}$} & \multirow[t]{2}{*}{ Name } & \multirow[t]{2}{*}{ Value } \\
\hline Code & Description & A1 & A2 & B1 & B2 & B3 & & & & \\
\hline $\mathrm{B} / \mathrm{E}$ & Land cleanly shaven & 3 & -2 & 3 & 3 & 2 & -48 & $-\mathrm{D}$ & $\mathrm{B} / \mathrm{E}$ & -4 \\
\hline $\mathrm{P} / \mathrm{C}$ & $\begin{array}{l}\text { Site preparation and } \\
\text { excavation }\end{array}$ & 1 & -1 & 3 & 3 & 2 & -8 & $-A$ & $\mathrm{P} / \mathrm{C}$ & -1 \\
\hline $\mathrm{B} / \mathrm{E}$ & $\begin{array}{l}\text { Road construction and } \\
\text { segmentation }\end{array}$ & 1 & -1 & 3 & 3 & 2 & -8 & $-\mathrm{A}$ & $\mathrm{B} / \mathrm{E}$ & -1 \\
\hline $\mathrm{P} / \mathrm{C}$ & Drainage changes & 3 & -2 & 3 & 3 & 2 & -48 & $-\mathrm{D}$ & $\mathrm{P} / \mathrm{C}$ & -4 \\
\hline $\mathrm{P} / \mathrm{C}$ & Digging and building & 1 & -1 & 2 & 3 & 2 & -7 & $-\mathrm{A}$ & $\mathrm{P} / \mathrm{C}$ & -1 \\
\hline $\mathrm{P} / \mathrm{C}$ & Waste production & 1 & -1 & 3 & 2 & 2 & -7 & $-\mathrm{A}$ & $\mathrm{P} / \mathrm{C}$ & -1 \\
\hline $\mathrm{P} / \mathrm{C}$ & $\begin{array}{l}\text { Human and industrial } \\
\text { wastewater treatment plants }\end{array}$ & 1 & 2 & 3 & 2 & 2 & 14 & $\mathrm{~B}$ & $\mathrm{P} / \mathrm{C}$ & 2 \\
\hline $\mathrm{P} / \mathrm{C}$ & $\begin{array}{l}\text { Collection and disposal of } \\
\text { waste }\end{array}$ & 2 & -2 & 3 & 3 & 2 & -32 & $-\mathrm{C}$ & $\mathrm{P} / \mathrm{C}$ & -3 \\
\hline $\mathrm{P} / \mathrm{C}$ & $\begin{array}{l}\text { Establishment and operation } \\
\text { of fuel tanks }\end{array}$ & 1 & -1 & 2 & 2 & 1 & -5 & $-\mathrm{A}$ & $\mathrm{P} / \mathrm{C}$ & -1 \\
\hline $\mathrm{P} / \mathrm{C}$ & $\begin{array}{l}\text { Compressor, welder and } \\
\text { generator activities }\end{array}$ & 1 & -1 & 2 & 2 & 2 & -6 & $-\mathrm{A}$ & $\mathrm{P} / \mathrm{C}$ & -1 \\
\hline $\mathrm{P} / \mathrm{C}$ & $\begin{array}{l}\text { Assembly of equipment and } \\
\text { tanks }\end{array}$ & 1 & -1 & 2 & 2 & 2 & -6 & $-\mathrm{A}$ & $\mathrm{P} / \mathrm{C}$ & -1 \\
\hline $\mathrm{P} / \mathrm{C}$ & $\begin{array}{l}\text { Camps, buildings and } \\
\text { workshops construction }\end{array}$ & 1 & -1 & 2 & 3 & 2 & -7 & $-\mathrm{A}$ & $\mathrm{P} / \mathrm{C}$ & -1 \\
\hline $\mathrm{P} / \mathrm{C}$ & $\begin{array}{l}\text { Well plat form, water and } \\
\text { solid waste pit construction }\end{array}$ & 2 & -2 & 3 & 2 & 3 & -32 & $-\mathrm{C}$ & $\mathrm{P} / \mathrm{C}$ & -3 \\
\hline $\mathrm{P} / \mathrm{C}$ & $\begin{array}{l}\text { The construction of oil } \\
\text { pipelines, gas and water }\end{array}$ & 1 & -1 & 3 & 3 & 2 & -8 & $-\mathrm{A}$ & $\mathrm{P} / \mathrm{C}$ & -1 \\
\hline $\mathrm{P} / \mathrm{C}$ & Well Drilling & 2 & -1 & 3 & 3 & 2 & -16 & $-B$ & $\mathrm{P} / \mathrm{C}$ & -2 \\
\hline $\mathrm{E} / \mathrm{O}$ & Manpower employment & 2 & 2 & 3 & 3 & 2 & 32 & $\mathrm{C}$ & $\mathrm{E} / \mathrm{O}$ & 3 \\
\hline $\mathrm{S} / \mathrm{C}$ & Land ownership & 1 & -2 & 3 & 3 & 2 & -16 & $-B$ & $\mathrm{~S} / \mathrm{C}$ & -2 \\
\hline
\end{tabular}

Table 9. Pastakia matrix in operational phase

\begin{tabular}{|c|c|c|c|c|c|c|c|c|c|c|}
\hline \multicolumn{2}{|r|}{ Components } & \multicolumn{5}{|c|}{ RIAM Criteria Scores } & \multirow{2}{*}{$\frac{\text { Score }}{\text { ES }}$} & \multirow{2}{*}{$\frac{\text { Value }}{\text { RV }}$} & \multirow[t]{2}{*}{ Name } & \multirow[t]{2}{*}{ Value } \\
\hline Code & Description & A1 & A2 & B1 & $\mathrm{B} 2$ & B3 & & & & \\
\hline $\mathrm{P} / \mathrm{C}$ & The operation of the units & 2 & -2 & 3 & 3 & 2 & -32 & $-\mathrm{C}$ & $\mathrm{P} / \mathrm{C}$ & -3 \\
\hline $\mathrm{P} / \mathrm{C}$ & $\begin{array}{l}\text { Management and collection } \\
\text { of waste }\end{array}$ & 2 & 2 & 3 & 3 & 2 & 32 & $\mathrm{C}$ & $\mathrm{P} / \mathrm{C}$ & 3 \\
\hline $\mathrm{P} / \mathrm{C}$ & $\begin{array}{l}\text { food, products and } \\
\text { personnel transportation }\end{array}$ & 1 & -1 & 3 & 2 & 2 & -7 & $-A$ & $\mathrm{P} / \mathrm{C}$ & -1 \\
\hline $\mathrm{P} / \mathrm{C}$ & $\begin{array}{l}\text { Waste collection and } \\
\text { management }\end{array}$ & 2 & 2 & 3 & 3 & 2 & 32 & $\mathrm{C}$ & $\mathrm{P} / \mathrm{C}$ & 3 \\
\hline $\mathrm{P} / \mathrm{C}$ & Extraction of groundwater & 2 & -2 & 3 & 3 & 3 & -36 & $-\mathrm{D}$ & $\mathrm{P} / \mathrm{C}$ & -4 \\
\hline $\mathrm{E} / \mathrm{O}$ & Hiring employees & 2 & 2 & 3 & 2 & 2 & 28 & $\mathrm{C}$ & $\mathrm{E} / \mathrm{O}$ & 3 \\
\hline $\mathrm{S} / \mathrm{C}$ & Welfare Services & 2 & 1 & 3 & 3 & 2 & 16 & B & $\mathrm{S} / \mathrm{C}$ & 2 \\
\hline $\mathrm{P} / \mathrm{C}$ & $\begin{array}{l}\text { Commissioning of chimneys } \\
\text { and burners }\end{array}$ & 2 & -3 & 3 & 3 & 2 & -48 & $-\mathrm{D}$ & $\mathrm{P} / \mathrm{C}$ & -4 \\
\hline
\end{tabular}


the mentioned impacts can be referred to as erosion, loss of vegetation, dust generation and its environmental, hygienic, social impacts and contamination of ground water.

The only positive impact is manpower employment, which can be a potential for education on environmental sensitivity to reduce the negative impacts (Dagiliūté, Juozapaitienè 2015).

In the operational phase, after classification of negative impacts, it was found that the operation of the units (A1) and extraction of groundwater (A5) have the most negative impacts (are classified in -D class). A1 causes air, soil and water pollution and can be spread to a large radius as well (especially about air pollution). A5 causes excessive groundwater depletion and other secondary impacts such as land subsidence. It should be noted that the land subsidence due to groundwater depletion in Iran's arid and semi-arid regions has become a very serious problem recently. In addition, reduction of ground water will have a significant impact on agricultural and livelihoods in a rural area. On the other hand, commissioning of chimneys and burners (A8) and food, products and personnel transportation (A3) are the next priorities that are placed in the $-\mathrm{C}$, respectively. Both activities have been causing air pollution and due to the blowing wind in the region, induce wide range impacts as well.

In order to compare present studies results with other traditional methods, research data were placed in Pastakia matrix and the evaluation was implemented with this method. The result of Pastakia matrix in constructional phase has been shown in Table 8 and in operational phase has been presented in Table 9.

As shown, in about $30 \%$ of activities such as A3, A7 and A9 in the constructional phase and A6 in the operational phase, respectively, the results of Pastakia and PROMETHEE are the same. But about $50 \%$ of the alternatives such as A1, A2, A8, A11, A14, A15 and A17 in the constructional phase and A1, A2, A3, A4, A5 and A7 alternatives, the results were close to each other. About differences between the two methods, some reasons can be pointed. Most of the time Pastakia matrix is filled by one expert, which can cause errors. In PROMETHEE method, criteria weighting is more accurate and mathematical formula and matrix in the PROMRTHEE matrix are more reliable. As the result, oil and petrochemical industries, due to association with fossil fuel, release huge amounts of pollution into the air, soil, water and other environmental components. The results from this study can be beneficial for environmental protection. This assertion by illustrating PROMRTHEE can be a useful method for resolving qualitative problems such as environmental issues. Therefore, these results can be used in future studies to prevent creating more global and national environmental problems.

\section{Conclusions}

This study examined the continued effects of petrochemical development (mostly construction and operation phases) on the environment. Activities with impacts on the environment include impacts on biophysical environments, biodiversity, and other resources were identified using the PROMETHEE technique that sophisticated plans are needed to avoid them. The PROMETHEE technique defined the preference functions and function calculations. The net outranking flows were calculated to determine the relative desirability of each alternative mode in the phases and to rank them as well. The comparison between results of Pastakia matrix and PROMETHEE techniques showed that the proposed method is an efficient technique. It is justified to use this method for determining the impacts of petrochemical project activities. Due to large volumes of quantitative and qualitative data in the environmental impact assessment of petrochemical industry and given the importance of national and international experts' opinions and decision-makers' ideas in this industry, the PROMETHEE properties such as high accuracy, enough details, ease of use, easy mathematical formulas, considering decision-makers and stakeholders opinions and converting qualitative data into quantitative data are some of its advantages for environmental impact assessment of petrochemical industries. Also, the PROMETHEE method doesn't cost much. In addition, this method is not limited to any specific time scale and there is no restriction in the geographical zone as well. One of the most important problems in this study was the lack of data. This deficiency was observed in Arak petrochemical company, libraries, and public relation agencies as well. However, the PROMETHEE can easily resolve this problem. It is a powerful tool for solving problems, including conflicting criteria and in some situations the problems that cannot be easily measured in the numerical terms. According to variable geographic, vegetation and climatic conditions in EIA projects, the PROMETHEE's sensitive analyses and high accuracy, any small changes in criteria weights, appropriate functions, threshold parameters and restriction levels can change the final results. In PROMETHEE, different criteria have different weights. Since, in some EIA methods, all of the criteria have the same weights, this methodology allows the decision-makers to make their decisions individually or in a group simultaneously.

\section{References}

Abdi, N. 2008. Evaluation of endangered plants biodiversity in Markazi province, Journal of Genetics Research and Reform of Pastures and Forests in Iran 16: 50-74 (in Persian).

Abromas, J.; Kamičaitytė-Virbašienè, J.; Ziemel̦niece, A. 2015. Visual impact assessment of wind turbines and their farms on landscape of Kretinga region (Lithuania) and Grobina townscape (Latvia), Journal of Environmental Engineering and Landscape Management 23(1): 39-49.

https://doi.org/10.3846/16486897.2014.919921

Achillas, C.; Vlachokostas, C.; Moussiopoulos, N.; Banias, G. 2011. Prioritize strategies to confront environmental deterioration in urban areas: multicriteria assessment of public opinion and experts' views, Cities 28(5): 414-423. 
Al-Rashdan, D.; Al-Kloub, B.; Dean, A.; Al-Shemmeri, T. 1999. Environmental impact assessment and ranking the environmental projects in Jordan, European Journal of Operational Research 118(1): 30-45.

https://doi.org/10.1016/S0377-2217(97)00079-9

Amaral, T. M.; Costa, A. P. 2014. Improving decision-making and management of hospital resources: an application of the PROMETHEE II method in an Emergency Department, Operations Research for Health Care 3(1): 1-6. https://doi.org/10.1016/j.orhc.2013.10.002

Ansari, A. 2015. Investigation of Arak air pollution source, in The First National Conference of Functional Researches in Conservation of Environment, Water and Natural Resources (in Persian).

Asgharpour, M. J. 2011. Multi-criteria decision making. $9^{\text {th }}$ ed. Tehran university publications.

Behzadian, M.; Kazemzadeh, R. B.; Albadvi, A.; Aghdasi, M. 2010. PROMETHEE: a comprehensive literature review on methodologies and applications, European Journal of Operational Research 200(1): 198-215.

https://doi.org/10.1016/j.ejor.2009.01.021

Benabied, S.; Goucem, S.; Bendjenna, H. 2012. Prom Choq: a multi criteria decision, aid method for actions ranking, International Journal of Computer Applications 55(6): 45-52.

Brans, J. P.; Mareschal, B. 1994. The PROMCALC \& GAIA decision support system for multi-criteria decision aid, Decision Support Systems 12(4-5): 297-310.

https://doi.org/10.1016/0167-9236(94)90048-5

Broucek, J. 2014. Production of methane emissions from ruminant husbandry: a review, Journal of Environmental Protection 5(15): 1482. https://doi.org/10.4236/jep.2014.515141

Cloquell-Ballester, V. A.; Monterde-Díaz, R.; Cloquell-Ballester, V. A.; Santamarina-Siurana, M. C. 2007. Systematic comparative and sensitivity analyses of additive and outranking techniques for supporting impact significance assessments, Environmental Impact Assessment Review 27(1): 62-83. https://doi.org/10.1016/j.eiar.2006.08.005

Corrente, S.; Figueira, J. R.; Greco, S. 2014. The smaa-promethee method, European Journal of Operational Research 239(2): 514-522. https://doi.org/10.1016/j.ejor.2014.05.026

Dagiliūtè, R.; Juozapaitienè, G. 2015. Socio-economic assessment in environmental impact assessment: experience and challenges in Lithuania, Journal of Environmental Engineering and Landscape Management 23(3): 211-220.

https://doi.org/10.3846/16486897.2015.1002842

Deng, X.; Hu, Y.; Deng, Y.; Mahadevan, S. 2014. Environmental impact assessment based on D numbers, Expert Systems with Applications 41(2): 635-643.

https://doi.org/10.1016/j.eswa.2013.07.088

Duarte, O. G.; Requena, I.; Rosario, Y. 2007. Fuzzy techniques for environmental impact assessment in the mineral deposit of Punta Gorda (Moa, Cuba), Environmental Technology 28(6): 659-669. https://doi.org/10.1080/09593332808618826

Esmaeilzadeh, M.; Mohammadshahi, S. 2009. Purge gas recovery in ammonia plants, in Conference of Carbon Market and Clean Development Mechanism in Petrochemical and Allied Industry (in Persian).

Gilbuena, R.; Kawamura, A.; Medina, R.; Amaguchi, H.; Nakagawa, N.; Du Bui, D. 2013. Environmental impact assessment of structural flood mitigation measures by a rapid impact assessment matrix (RIAM) technique: a case study in Metro Manila, Philippines, Science of the Total Environment 456: 137-147. https://doi.org/10.1016/j.scitotenv.2013.03.063
Greco, S.; Figueira, J.; Ehrgott, M. 2005. Multiple criteria decision analysis. Springer's International series.

Hosseini, S. A.; Mazrae, M. R.; Lotfalian, M.; Parsakhoo, A. 2012. Designing an optimal forest road network by consideration of environmental impacts in GIS, Journal of Environmental Engineering and Landscape Management 20(1): 58-66. https://doi.org/10.3846/16486897.2012.662748

Howarth, R. W. 2015. Methane emissions and climatic warming risk from hydraulic fracturing and shale gas development: implications for policy, Energy and Emission Control Technologies 3: 45-54. https://doi.org/10.2147/EECT.S61539

Huang, P. H.; Tsai, J. S.; Lin, W. T. 2010. Using multiple-criteria decision-making techniques for eco-environmental vulnerability assessment: a case study on the Chi-Jia-Wan Stream watershed, Taiwan, Environmental Monitoring and Assessment 168(1): 141-158. https://doi.org/10.1007/s10661-009-1098-Z

Iran Environmental Protection Agency. 2011. Hand book of hunting guide (in Persian).

Jafari, H. 2013. Measuring the performance of dry bulk cargo loading and unloading operation: Latakia Case Study, Journal of Business and Management Sciences 1(5): 77-82.

Kabir, G.; Sumi, R. S. 2014. Power substation location selection using fuzzy analytic hierarchy process and PROMETHEE: a case study from Bangladesh, Energy 72: 717-730. https://doi.org/10.1016/j.energy.2014.05.098

Karam, A.; RanjbarBarough, Z.; Mohamadian, E. 2014. An investigation on Topography effect on Arak air pollution, The First Conference on Iran Geographical Science (in Persian).

Kaya, T.; Kahraman, C. 2011. An integrated fuzzy AHP-ELECTRE methodology for environmental impact assessment, $E x$ pert Systems with Applications 38(7): 8553-8562. https://doi.org/10.1016/j.eswa.2011.01.057

Khodabakhshi, B.; Jafari, H. R. 2010. Environmental impact assessment of water resources development projects using the ELECTRE TRI model (a case study of Ardebil reservoir, drainage, and irrigation network), Journal of Water and Wastewater 3: 64-74 (in Persian).

Kiker, G. A.; Bridges, T. S.; Varghese, A.; Seager, T. P.; Linkov, I. 2005. Application of multi-criteria decision analysis in environmental decision making, Integrated Environmental Assessment and Management 1(2): 95-108.

https://doi.org/10.1897/IEAM_2004a-015.1

Latawiec, A. E.; Peake, L.; Baxter, H.; Cornelissen, G.; Grotkiewicz, K.; Hale, S.; Królczyk, J. B.; Kubon, M.; Łopatka, A.; Medynska-Juraszek, A.; Reid, B. J. 2017. A reconnaissancescale GIS-based multicriteria decision analysis to support sustainable biochar use: Poland as a case study, Journal of Environmental Engineering and Landscape Management 25(2): 208-222. https://doi.org/10.3846/16486897.2017.1326924

Lotfi, F. H.; Fallahnejad, R. 2010. Imprecise Shannon's entropy and multi attribute decision making, Entropy 12(1): 53-62. https://doi.org/10.3390/e12010053

National Petrochemical Company (NPC). 2016. Complexes of petrochemical industry (in Persian).

Norouzi, F.; Shamsipour, A. 2015. The effect of climate factors in reducing or increasing of Arak air pollution, International Conference on Science, Engineering and Environmental Technologies (in Persian).

Olivier, J. G. J.; Janssens-Maenhout, G.; Muntean, M.; Peters, J. A. H. W. 2015. Trends in global CO2 emissions: 2015 Report. PBL.

Papadopoulou, M. P.; Antoniou, C. 2014. Environmental impact assessment methodological framework for liquefied natural gas terminal and transport network planning, Energy Policy 68: 306-319. https://doi.org/10.1016/j.enpol.2014.01.044 
Pastakia, C. M.; Jensen, A. 1998. The rapid impact assessment matrix (RIAM) for EIA, Environmental Impact Assessment Review 18(5): 461-482.

https://doi.org/10.1016/S0195-9255(98)00018-3

Pennington, D. W.; Potting, J.; Finnveden, G.; Lindeijer, E.; Jolliet, O.; Rydberg, T.; Rebitzer, G. 2004. Life cycle assessment Part 2: Current impact assessment practice, Environment International 30(5): 721-739. https://doi.org/10.1016/j.envint.2003.12.009

Peszko, G.; Artuykhina, G.; Van den Berg, K.; Eleuova, K.; Hildrews, J.; Inuytin, S.; Kireyev, M.; Krzyżanowski, P.; Van Woerden, F. 2006. Minimizing environmental impacts of industrial growth: case study of petrochemical industry in Kazakhstan. (No. 13019). The World Bank.

Raesi, A.; Bijani, M. 2016. Environmental sustainable development strategies for dealing with pollution of natural resources, in The National Conference on Horizon Scanning of the Earth with an Emphasis on Agriculture and the Environment (in Persian).

Rodrigues, G. S.; Campanhola, C.; Kitamura, P. C. 2003. An environmental impact assessment system for agricultural R\&D, Environmental Impact Assessment Review 23(2): 219-244. https://doi.org/10.1016/S0195-9255(02)00097-5
Saket, M. 2016. Petrochemical industry position in the value chain, in The $5^{\text {th }}$ Conference on Islamic-Iranian Model of Progress (in Persian).

San Cristóbal, J. R. 2012. Multi criteria analysis in the renewable energy industry. Springer Science \& Business Media. https://doi.org/10.1007/978-1-4471-2346-0

Sharafi, S. M.; Makhdoum, M.; Ghafourian, B. M. M. 2008. Environmental impact assessment case study: automobile industry in Takestan, 27-42.

Simion, I. M.; Fortuna, M. E.; Bonoli, A.; Gavrilescu, M. 2013. Comparing environmental impacts of natural inert and recycled construction and demolition waste processing using LCA, Journal of Environmental Engineering and Landscape Management 21(4): 273-287. https://doi.org/10.3846/16486897.2013.852558

Suopajärvi, L. 2013. Social impact assessment in mining projects in Northern Finland: comparing practice to theory, Environmental Impact Assessment Review 42: 25-30. https://doi.org/10.1016/j.eiar.2013.04.003

Wang, Y. M.; Yang, J. B.; Xu, D. L. 2006. Environmental impact assessment using the evidential reasoning approach, European Journal of Operational Research 174(3): 1885-1913. https://doi.org/10.1016/j.ejor.2004.09.059 